laços que o unem aos outros homens, aos vivos e aos mortos, pelo culto que dedica aos mortos pelos serviços que presta aos vivos. Não digo isso como crente, mas como sociólogo, profundamente respeitoso por tôdas as crenças sinceras, mas que se presume liberto de todo o dogma e de todo o preconceito".

Essas palavras leais de Duguit parece terem frutificado. 0 tratados recentes sôbre filosofia do direito e sôbre direito público, onde o conceito de direito natural revive purificado das deformações que sofrera, estão impregnados das idéias e dos princípios que inspiraram os grandes sistemas jurídico-morais de Sto. Tomaz de Aquino e Sto. Agostinho, de Belarmino e Suarez.

$\mathrm{E}$ é de esperar que o século $\mathrm{XX}$, mau-grado os momentos tumultuosos que o mundo atravessa, restaurará a obra demolida pelo racionalismo do século XVIII e pelo materialismo do século XIX.

O Direito, repôsto sôbre bases perenes, inspirado por princípios morais universais, não será um instrumento de luta e de opressão, mas uma norma de justiça, de paz e de fraternidade entre os homens.

\section{O JÚRI E A SUA COMPETÊNCIA FIXADA PELA CONSTITUIÇÃO}

\section{José Salgado Martins}

Ainda se controverte a competência do júri, instituída obrigatòriamente pela Constituição Federal, art. 141, § 28, no que tange "aos crimes dolosos contra a vida".

Desde a discussão no Senado, apresentado o projeto $n .^{\circ} 1$, de autoria do ilustre senador Olavo Oliveira, que se constituíram duas correntes, no sentido de interpretar o texto constitucional.

O projeto do senador Olavo Oliveira, objetivando conciliar a lei ordinária com a lei magna da República, fixava a competência do júri relativamente a "todos os crimes dolosos, de qualquer espécie, de cuja prática resulte morte, seja qual fôr a sua capitulação".

O substitutivo, apresentado a êsse projeto pela Comissão de Constituição e Justiça do Senado, reduzia a competência ao julgamento dos crimes definidos pelo Código Penal de 1940, no Capítulo I do Tí́tulo I, sob a denominação de "crimes contra a vida".

Essa, orientação prevaleceu, afinal, e assim dispõe a Lei n. ${ }^{\circ} 263$ de 23 de fevereiro de 1948, que, modificando dispositivos do Código de Processo Penal, teve em mira afeiçoar a instituição do júri aos. princípios adotados pelo Estatuto Fundamental da República.

Sem embargo da lei ordinária haver se inclinado pela interpretação restritiva da competência do júri, a controvérsia não se encerrou; pois, na jurisprudência e na doutrina, surgem autorizadas opiniões que reivindicam para o júri a ampla competência que, obrigatòriamente, the deferiu a Constituição Federal, no tocante a todos os crimes dolosos de que resulte morte, seja êste evento querido pelo agente, ou seja conseqüência do simples risco assumido, através da prática de antecedente crime doloso.

A tese envolve matéria de alta relevância.

Cumpre examinar os argumentos em que se apóiam as correntes em luta e dêles inferir à qual delas cabe a procedência e a harmonia com o texto constitucional, a que deverá ceder o passo a lei ordinária.

$\mathrm{O}$ projeto n. $^{\circ} 1$, de autoria do senador Olavo Oliveira, professor catedrático de Direito Penal da Faculdade do Ceará, dispunha no artigo $2 .^{\circ}$ : 
"Competirá privativamente ao Tribunal do Júri o julgamento: a) dos crimes previstos nos artigos $121, \S \S 1 .^{\circ}$ e $2 .^{\circ}, 122$ e parágrafo único, $123,124,126,127,129, \S 3 . \circ, 137, \S$ único, $157, \S 3 .^{\circ}$, 159 , $3 .^{\circ}, 210$, comb. com o 223 , $\$$ único, 214 , comb. com o 223 , $\S$ único, 219, comb. com o 223, § único, do Código Penal;

b) dos crimes de perigo comum e contra a segurança dos meios de comunicação e transporte e outros serviços, e contra a saúde pública, dos quais resulte morte;

c) da tentativa, quando possível, de qualquer dos referidos crimes;

d) dos delitos de imprensa" ( $\left.{ }^{1}\right)$.

A Comissão de Constituição e Justiça do Senado ofereceu substitutivo, reduzindo a competência do júri e restringindo-a aos delitos previstos nos artigos $121,121 \S \S 1^{\circ}$ e $2 .^{\circ}, 122,123,124,125,126$ e 127 do Código Penal, assim como dos que com êles forem conexos (artigo 2..$^{\circ}$ do Substitutivo) e, no $\$$ único do mesmo art. $2 .^{\circ}$, ainda dispôs que os delitos de imprensa continuarão a ser julgados pelo júri organizado de acôrdo com a legislação especial em vigor".

O senador Olavo Oliveira combateu o substitutivo e apresentou, entre outras, uma emenda ao artigo $2 .^{\circ}$, restabelecendo a orientação do seu projeto, isto é, estendendo a competência do júri "a todos os crimes dolosos, de cuja prática resulte morte, seja qual fôr a sua capitulação, assim como os que com êles forem conexos, e da tentativa, quando possível, dos referidos crimes".

Justificando a emenda, o seu autor invoca a lição de Carrara quanto ao conceito de dolo, e à sua bipartição em dolo determinado (ed è quello che si constituisce dalla intenzione diretta) e em dolo indeterminado (ed è quello che si ravvisa nella intenzione indiretta positiva che ad alcuni piacque chiamare alternativa).

Citando ainda Eugênio Florian e Jorge Vidal, insiste na divisão entre dolo direto e dolo indireto, para, afinal, concluir que o nosso Código adotou a aludida dicotomia em matéria de dolo, considerando como o da última espécie aquêle em que, segundo a linguagem do Código, o agente assumiu o risco de produzir o resultado.

"Há duas modalidades de crimes dolosos contra a vida:

a) os cometidos com dolo direto e específico, constante do “animus necandi” (Código Penal, arts. 121, $\$ 1 .^{\circ}$ e 2. ${ }^{\circ}, 122,123$, $124,125,126$ e 127

b) os praticados com dolo indireto ou eventual, na realização de outro delito, do qual resultam, como conseqüência, cujo risco consciente cabe ao agente.

Tais são, por exemplo, as figuras qualificadas, com o evento "morte de alguém", dos crimes de rixa (art. 137, § único, latrocínio

(1) O Júri na Terceira República, Olavo Oliveira, Rio, 1949, p. 10. (art. 157, $33^{\circ}$ ), seqüiestro (art. 159, $\$ 3 .^{\circ}$ ), estupro (art. 213 , combinado com $o$ art. 223, $\S$ único), atentado violento ao pudor (art. 214, comb. 223, § único) e rapto (art. 219, combinado com 223 , $\$$ único).

Em todos êsses casos e em numerosos outros semelhantes, dos quais salientamos os catalogados na alínea "b" do art. $20^{\circ}$ do projeto primitivo, há uma entidade penal complexa, mista de dois crimes a) - do crime doloso direto ou específico, previsto pelas leis penais, na conformidade da objetividade jurídica violada - patrimônio, liberdade sexual, etc. - b) - do delito doloso indireto ou eventual contra a vida, nascido do primeiro" $\left({ }^{2}\right)$.

Combatendo a emenda, apresentada pelo senador Olavo Oliveira ao substitutivo, o ilustre senador Ferreira de Souza.sustentou que, na expressão "crimes dolosos contra a vida", o legislador quis apenas referir-se "aos casos de dolo direto, em que a vontade inicial e evento se casaram, visando ambos à vida". Acrescentou o nobre parlamentar: "Se o crime não se reduz ao evento, mas exige o ato como manifestação inicial da vontade do agente, como causa voluntária do mesmo evento, o dolo que o caracteriza é o inicial, o que moveu o agente, o que lhe determinou a ação ou a omissão". Concluiu, finalmente, o mesmo senador: "Se a ação não visando à vida, a lesa, êsse fato não chega a constituir um novo crime, pois a lesão é dolosa, não porque o agente tenha tido a intenção de praticá-la correspondendo o fato ao "animus necandi", mas simplesmente pela extensão do dolo às conseqüências possiveis da ação ou omissão do agente. (O grifo é nosso) ${ }^{3}$ ).

Nos próprios conceitos, exarados pelo ilustre senador Ferreira de Souza, na parte final do seu parecer, perante o Senado, encontrase a defesa da nossa tese. Ora, se considera o dolo extensivo às conseqüências possíveis da ação ou omissão do agente e se, entre essas conseqüências, está a morte da pessoa, o crime é necessàriamente doloso contra a vida, ainda que a finalidade específica e primária do agente fôsse atingir e lesar bem jurídico diverso daquele ( $\left.{ }^{3 a}\right)$.

(2) Ob. cit., p. $36 / 7$ dolosos contra a vida"

Em voto vencido, o ilustre desembargador La Hire Guerra, figura singular da magistratura rio-grandense, pelas suas peregrinas virtudes morais e pelos seus dotes as crimes de que resulte dolosamente a morte: " $\mathrm{Em}$ face do estatuído na Constituição Federal - art. 141, \& 28, in fine mesma de prevalecer sôbre a do juiz singular. 0 dispositivo constitucional teve em mir resguardar a liberdade individual contra o suposto rigorismo da justiça singular e pro-

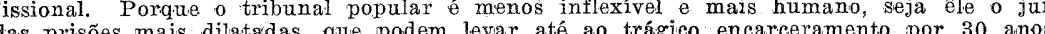
Fôra, pois, disvirtuar o sentido da nossa lei máxima, reduzi-la a uma questão de nome jurídico - aplicável restritamente ao caso de homicidio pròpriamente dito - previsto no capitulo 1. do tratio 1.é da parime voluntário do augl resultou morte ainda que esta aão tenha sido a intencão direta ou principal do criminoso, mas fôsse simples meio para
axecucão de crime diverso, tal como sucede, entre outras, nas hipóteses dos arts. 146 \$ 
Rejeitada a emenda, prevaleceu o substitutivo da Comissão, que depois, remetido à Câmara, foi aprovado e assim constituído o texto da lei vigente (Lei n. 263 cit.).

Afigura-se-nos que o poder legislativo não atendeu à vontade da lei constitucional, expressa no $\$ 28$ do art. 141, quando prescreveu que coubesse, obrigatòriamente, ao julgamento do júri todos os crimes dolosos contra a vida.

Parece-nos que predominou um verdadeiro preconceito na legislatura ordinária, quando lhe tocou regulamentar o dispositivo constiuucional.

Elaborou a lei ordinária, sob o pressuposto, inteiramente incabível, de que o legislador constituinte, ao usar da expressão "crimes. dolosos contra a vida", tinha em mente designar somente os crimes. assim contemplados, segundo a nomenclatura do Código Penal.

Deu assim uma primazia ao Código Penal sôbre a Constituição. Ao invés daquele ser interpretado em função do ordenamento jurídico, estruturado na Constituição, é a Constituição que, segundo a estranha exegese, passou a ser compreendida segundo os princípios: sistemáticos do Código, no tocante à classificação dos delitos.

O legislador constituinte estabeleceu princípios fundamentais dos quais haveriam de dimanar as conseqüências jurídicas no campo do direito público e no próprio campo do direito privado.

De resto, ainda que a intenção fôsse no sentido de compreender apenas os crimes definidos sob a rubrica "crimes contra a vida", segundo o Código Penal, não poderia prevalecer essa intenção, por isso que a lei se independiza da vontade do legislador e o sentido e o âmbito de sua aplicação resultam não daquela vontade, mas da função que passa a desempenhar a lei, em consonância com o ordenamento jurídico geral, dentro dos pincípios que estruturam o sistema a que pertence.

"No se investiga, propiamente hablando, la voluntad del legislador, sino la de la ley. La voluntad de la ley vale más que la del legislador".

$2 \circ^{\circ}, 150, \& 10^{\circ}, 157, \& 3 .^{\circ}, 208, \&$ único, $223, \&$ único, $267, \& 1 .^{\circ}, 351, \& 22 .^{\circ}, 352$ e $\$ 53$ do Código Penal. Tôda a questão depende de achar-se ou não rêu sujeito às penas do as circunstâncias do caso terá de ser julgado pelo júri. No caso presente, a violênzicia arbitrária consistil precisamente em matar, o desígnio criminoso não foi outro seña o homicídio, a intenção única, e não apenas secundária ou indireta, foi o sacrifíício de ama a pena do art. 322 do Código Penal - deteñ gấo de 6 meses a 3 anos - os réus sujais àtos do homicídio doloso - tenho, data vêniat, como certeza juridica, a nulidade do julgamento, por infringente do art. $141 \& 28$ da Constituiçäo Federal". Ac. do Trib. de Justiça do R. G. do Sul, de 7-8-1947 in Rev. Forense, vol. CXV', pág. 237-38). Foi
relator do acórdão que sufraga a interpretaçăo que combatemos, o illastre Des. Cedsok Afonso Pereira.
"La interpretación es una operación lógico-juridica, consistente en verificar. el sentido que cobra el precepto interpretado, al ser confrontado con todo el ordenamiento juridico concebido como unidad, y especialmente ante ciertas normas que le son superiores o que sencillamente limitan su alcance, con relación a una hipótesis dada" ( $\left.{ }^{4}\right)$.

Ao interpretar, pois, o dispositivo constitucional, constante do art. $141, \S 28$, cumpre, em primeiro lugar, determinar a sua índole - natureza na sistemática dos direitos e das garantias individuais.

A Constituição de 1946 restaurou a soberania do júri, reatando a tradição democrática da primeira constituição republicana.

Ora, sempre se reconheceu como linha fundamental da instituição do júri a sua competência para o julgamento dos crimes mais graves a que a lei comina penas de longa duração.

Em segundo lugar, devemos atender para a locução "crimes dolosos contra a vida", interpretando-a no sentido que ela comporta dentro da doutrina penal, sem nos impressionarmos com a nomenclatura e o sistema do Código vigente, porque êste é que deve afeiçoar-se aos princípios da Constituição, de que é vassalo, e não està seguir o passo daquele.

A nossa assertiva não sufraga o conceito emitido, em aparte ao discurso do senador Olavo Oliveira, pelo ilustre senador José Ferreira de Souza, segundo o qual "o legislador constituinte não é técnico "em Direito Penal. Não fêz distinção perfeita do dolo”.

O legislador constituinte, ao concretizar a norma constante do $\$ 28$ do art. 141 da Constituição, deveria ter em mente os ensinamentos da doutrina penal e não a orientação do Código Penal, com os seus conceitos e as suas limitações.

No legislador constituinte são presumidos conhecimentos especializados e profundos de todos os ramos do direito, pois a todos a Constituição deve levar o seu reflexo, a sua ressonância e, sob o seu império, se organizam e se legitimam todos os setores do direito público e do próprio direito privado.

De resto, se verdadeira fôsse a afirmativa do nobre senador Ferreira de Souza, seria esta mais favorável do que contrária à nossa tese.

Porque, se realmente o constituinte não fôsse técnico em direito penal e não houvesse feito distinção perfeita do dolo, seria contraditório afirmar, ao mesmo tempo, que êle ficara adstrito ao Código, pois, segundo êsse diploma, êle deveria ter admitido duas modalidades do dolo, o chamado dolo direto, no qual a vontade corresponde ao resultado atingido (art. 15, al. I), e o dolo chamado weventual, no qual o agente, ao empreender o ato, tem a representa-

(4) Sebastian Soler, Der. Pen. Arg., Tomo I, p. 142-43. 
ção intelectual do resultado que, eventualmente, poderá dêle derivar (art. 15, al. 1, 2. a parte).

Mas, na realidade, o legislador constituinte empregou a locução "crimes dolosos contra a vida" com o rigor técnico que ela comporta na ciência penal, e não no sistema do Código.

Vejamos o que se entende por crime doloso.

O dolo pressupóe um ato psicológico complexo, cujo fundamento é a vontade orientada para um consciente fim ilícito. Entre a consciência do fim e a vontade de alcançá-lo, há no agente o conhecimento da ilicitude da ação, a persuasão de sua capacidade para obter o fim almejado e a previsão das consequiências que podem derivar do desencadeamento da ação.

"El resultado pensado por el sujeto como consecuencia necesaria de la acción es dolosamente querido. También ahora hay que partir del resultado intencional. A éste se añade, en primer término, un ulterior elemento de representación, a saber: la representación de que con el resultado intencionalmente perseguido están ligados, $y$, en verdad, necesariamente ligados, otros resultados ulteriores. Cuando existe esta situación de hecho, es ella ya suficiente por sí sola para designar como querido a este resultado necesario de la acción. La representación de la conexión necesaria, traslada también necesariamente la voluntad de la acción al resultado concebido como necesario. $Y$ es indiferente que este último sea deseado o no por el sujeto. Pues el efecto intencionalmente perseguido era para el autor, en tales casos, aún más deseado que la evitación de la consecuencia necesariamente ligada com él, y por ello, se le imputa al agente como querida, esta consecuencia necesaria. El que hace transportar en un navío una máquina infernal para que el buque se hunda en pleno Oceáno y percibir de esta suerte la prima del seguro, ha querido dolosamente la muerte de todas aquellas personas cuya pérdida prevé como cierta, aun cuando este "resultado accesorio" sea en absoluto contrario a su deseo. "Las consecuencias de la acción reconocidas como necesarias han sido admitidas por el agente en sua voluntad aun cuando no tenga interés alguno en dichas consecuencias".

En especial es, por tanto, dolosamente querido todo medio para la consecución del fin, que se representa al agente como necesario todo resultado accesorio que al sujeto se representa como necesariamente ligado con el resultado principal, toda ulterior consecuencia de la acción, representada como necesaria" (5).

Da mesma opinião é o consagrado mestre argentino Sebastian Soler, cujos conceitos no direito penal se inspiram nas melhores fontes e refletem um exemplar equilíbrio e irrepreensível correção.

"El dolo se integra no solamente por el conocimiento de las cir-

(5) Edmundo Mezger, Tratado de Derecho Penal, trad, esp., tomo II, p. 138.8. cunstancias presente, sino también por la representación de una situación futura a la cual tiende, o cuyo advenimiento el autor desea o, a lo menos, consiente. Ese estado futuro de cosas debe ser considerado como una unidad representativa, por cuanto existen en toda situación determinante de la voluntad una pluralidad de elementos que no todos son con igual intensidad deseados, $y$ aun, a veces, algunos de ellos no lo son. Puede uno querer la muerte de su enemigo sin desear por ello la miseria y el abandono de los hijos de éste, a pesar de representársela como necesaria.

Lo más frecuente, observa v. Hippel, es que en la representación del estado futuro "se entremezcle lo agradable con lo indiferente y con lo desagradable". Por eso es que la volición, y con ella el dolo. no importan un sentimiento de agrado o satisfación absoluta para el que realiza lo deseado, sino de agrado relativo. Diremos, pues, que existe dolo, no sobre la base de computar la referencia intencional del sujeto a cada uno de los eventos esperados, tomados aisladamente, sino con relación al conjunto de hechos considerados en sua unidad "con sus luces y sombras". Y es dolosa la totalidad de la representado, cuando uno de los elementos sobrepasó el poder de cohibición que las demás previsiones ejercían. Es decir, que doloso es no solamente aquello que fué indirectamente propuesto o intencional, sino todo aquello que apareció como acompañando necesariamente a ese hecho, aun cuando estas otras circunstancias no sean. aisladamente deseadas.' Así, es dolosa la lesión causada al que viajaba en el mismo coche que mi enemigo, cuando por vengarme de éste he hecho tumbar el carruaje, a pesar de que esa lesión a un tercero puede serme desagradable o indiferente. Ya en el Digesto, fr. $77,47,2$, hay de ello un buen ejemplo: qui saccum habentem pecuniam surripit, furti etiam sacci nomine tenetur, quamvis non sit ei animus sacci surripiendi" $\left({ }^{6}\right)$.

Logo, é doloso o delito não só quanto ao fim específico, visado, primàriamente, pelo agente, mas no tocante a tôdas as conseqüências que, segundo a experiência corrente e a ordinária previsão, se possam conter na prática do fato. Assim em todos os crimes em que o meio executivo é a violência contra a pessoa, o agente pode prever, conforme as circunstâncias em que exerce a violência, as conseqüências a que fica sujeita a pessoa e que vão da simples atemorização às. lesões corporais e à morte.

Ora, ainda que a violência vise dolosamente um fim específico, por exemplo, a obtenção de uma vantagem, a subtração de uma cousa, se, no entanto, em virtude do modo em que se exerce e das. condições do sujeito passivo, sobreveio uma conseqüência mais grave para a pessoa - a própria morte ou o evento lesões corporais - não

(6) Sebastian Soler, ob. eit., tomo II, p. 123-4 
se pode dissociar, do ponto de vista subjetivo, o dolo para reconhecê-lo, quanto aos atos ligados ao fim específico e negá-lo quanto às conseqüências resultantes dos próprios atos postos em prática.

Só será lícito negar o dolo, se essas conseqüências se mostrarem de caráter extraordinário, fruto puramente do fortuito, ou não suscetíveis de ordinária previsão, mas sòmente previsíveis, e, portanto não tenham se representado na mente do autor, como necessàriamente ou possivelmente ligadas à ação diretamente desejada.

Examinemos cada uma das hipóteses delituosas contempladas no Código, de que resulte a morte da pessoa.

Temos, em primeiro lugar, o crime de homicídio que se divide em três modalidades: homicídio simples, homicídio privilegiado homicídio qualificado, em que a morte da pessoa corresponde exatamente ao dolo do agente.

Depois, o crime de induzimento, instigação ou auxílio a sui cídio. Sòmente se constituem os pressupostos do delito, acarretando a conseqüência jurídica da pena, quando se consuma o suicídio ou de sua tentativa resulta lesão corporal de natureza grave.

Como é óbvio, sá surgirá a competência do júri na primeira hipótese, isto é, em se verificando a consumação do suicídio.

A seguir, vêm os crimes de infanticídio e de abôrto. Quanto ao último, surge, de logo, uma questão: o crime de abôrto, em tôdas as modalidades previstas pelo Código, está sujeito ao julgamento do júri, ou sòmente, quando do próprio abôrto ou dos meios empregados para provocá-lo, sobrevém a morte da gestante?

A nosso ver, sempre a competência é do júri, ainda que não sobrevenha a morte da gestante em conseqüência do abôrto ou dos meios empregados para provocá-lo.

A incriminação do abôrto destina-se a proteger, primacialmente, a vida do produto da concepção, a que se reúne, secundàriamente, o bem jurídico, representado pela saúde da gestante.

"O Código classifica o abôrto entre os crimes contra a vida que são uma subclasse dos crimes contra a pessoa. E' um critério acertado. Não se pode negar que o feto seja, pelo menos, uma "spes personae". O Código Civil Brasileiro, não obstante declarar que "a personalidade civil do homem começa do nascimento com vida", põe a salvo os direitos do nascituro e destaca situações em que, como observa Clóvis Beviláqua, o "infans conceptus" se apresenta como pessoa: a) art. 359, legitimação do filho apenas concebido; b) art. 357 , parágrafo único, reconhecimento de filho anterior ao nascimento c) art. 468, curatela do nascituro; c) art. 1718, capacidade do nascituro para adquirir por testamento. E comentando o art. $4 .^{\circ}$ do referido Código, disserta Clóvis: "Kohler recorre a uma construção forçada das pessoas jurídicas implícitas (stillschweigende juristische Personem) para explicar exercício dos direitos do nascituro; Windscheid fala, em tal caso, de direito sem sujeito. Parece mais lógico afirmar, francamente, a personalidade do nascituro'.

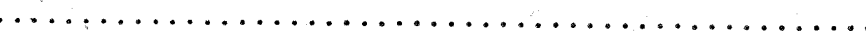

"Segundo ensina Manzini, o feto é, pelo menos, uma pessoa em formação, isto é, uma expectativa de vida humana, de modo que o abôrto provocado vem a ser um crime "contra a vida" $e$, in genere, "contra a pessoa". $O$ interêsse jurídico relativo à vida e à pessoa é lesado desde que se impede a aquisição da vida e da personalidade civil a um feto capaz de adquiri-las.

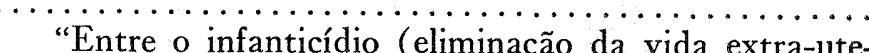
rina) e o abôrto (eliminação de vida intrauterina) a diferença é apenas de grau, ou, como dizia Carrara, de quantidade natural e de quantidade politica $\left({ }^{7}\right)$.

Logo, o abôrto é um crime doloso contra a vida e, portanto, seu julgamento incide obrigatòriamente na esfera jurisdicional do júri, ocorra ou não a morte da gestante.

Referidas as figuras delituosas em que o evento morte constitui - fim específico do agente, vejamos agora aquêles casos de crimes de estrutura complexa, como os denomina Carnellutti, em que ao evento diretamente querido pelo agente, acrescenta-se outro, intimamente ligado ao primeiro e compreendido como conseqüência necessária da própria ação, embora possa constituir o resultado - morte - um fato indiferente à esfera volicional do criminoso.

Temos, em primeiro lugar, segundo a ordem de enumeração dos delitos, adotada pelo Código, a figura da "lesão corporal seguida de morte" (art. 129, §3..$^{\circ}$, que a terminologia clássica denomina "homicídio preterintencional".

Poder-se-á considerá-la como crime doloso contra a vida?

Diante do Código penal vigente, não. Face à doutrina', sim e não, pois tudo depende do conceito e do alcance do dolo, conforme as várias concepções.

Para alguns autores, o delito preterintencional é, essencialmente, doloso; para outros, essencialmente, culposo e para a terceira corrente, aliás, a que prepondera na doutrina e na legislação, é um misto ou um delito complexo, de dolo e culpa, dolo no antecedente e culpa no conseqüente.

Ora, para os que entendem que o evento - morte - excedente da intenção do autor só pode ser imputado a título de culpa, parece

(7) Nelson Hưngria, Com. ao Código Penal, vol. V, págs. 248-50.

9 - R. F. D. 
que a consequêencia lógica levaria a excluir tal delito da competência do júri. No entanto, a nós se afigura arbitrária essa exclusão "in limine" ou aprioristicamente.

A distinção entre a lesão corporal seguida de morte e o autêntico homicídio doloso reside, principalmente, no elemento subjetivo.

Ora, sabemos como são enganadoras, muitas vêzes, as circunstâncias exteriores, através das quais se caminha para alcançar âmago do sentimento e do motivo que inspiraram e determinaram o criminoso, na prática do seu delito.

Há hipóteses em que se deve inferir necessàriamente o dolo, ainda que o negue o agente, por fôrça da eficácia mortífera do instrumento, da direção dos golpes, da região atingida, e de outras inúmeras circunstâncias ligadas à execução do crime.

Desde que se esteja em face do evento - morte - produzido mediante ação idônea e voluntária do homem, o fato constitui, pelo menos aparentemente, o crime de homicídio, e o elemento subjetivo constitui indagação posterior que sòmente se elucidará, no julgamento da causa: ao júri o crime deve ser submetido; e só a êle caberá julgar-se incompetente.

No capítulo dos "crimes de periclitação da vida e da saúde" pode ocorrer o evento morte, como elemento qualificativo do aban dono de incapaz, exposição ou abandono de recém-nascido, omissão de socorro e maus tratos.

No tocante ao crime de abandono (art. 13), a morte pode sobrevir como conseqüência necessária do próprio abandono.

Figure-se a hipótese de um menor de tenra idade, abandonado numa floresta ou em região absolutamente êrma, visitada por animais de prêsa.

Pode a morte não ter sido desejada pelo agente, constituindo mesmo para êle uma "hipótese desagradável", mas, conforme as circunstâncias, ligadas ao grave risco e conseqüente dano sofrido pelo abandonado, ao agente o evento morte se apresentará como conseqüência ordinária do abandono, relacionando-se, pois, ìntimamente ao dolo específico do crime. Nesse caso, o crime de abandono pode ter constituído apenas a ocasião para o crime de homicídio e, precisamente por isso, é necessário distinguir, com argúcia, tôdas essas situações, projetando muita luz sôbre as sombras que se adensam em tôrno dos verdadeiros motivos e circunstâncias do crime.

$\mathrm{O}$ mesmo pode ocorrer, no tocante aos delitos previstos nos artigos 134 (exp. ou abandono do recém-nascido) 135 (omissão de socorro) e 136 do Código (maus tratos).

Preferível é exemplificar, para que mais clara se mostre a possibilidade de, sob a aparência de tais delitos, se concretizar um verdadeiro delito doloso de homicídio, da competência do júri.

\section{ABANDONO OU EXPOSIÇÃO DE RECÉM-NASCIDO}

Uma mãe desalmada manda abandonar o filho recém-nascido, colocando-o sob chuva inclemente, à porta de uma casa que sabe sem moradores. Ainda que no seu espírito se represente a possibilidade de algum transeunte recolher a criança e tomá-la sob seus cuidados, a representação do evento morte, que vem de ocorrer, se impóe, no momento do abandono, como um fato que se contém nas condições causais do próprio abandono.

\section{CRIME DE OMISSÃO DE SOCORRO}

Um médico encontra na estrada um indivíduo ferido que está prestes a expirar, em conseqüência de forte hemorragia. Ao médico seria relativamente fácil estancar a hemorragia, mercê de recursos que, na ocasião, dispõe. Mas, como se trate de um inimigo, deixa que o ferido pereça, sem lhe prestar a mínima assistência.

Aparentemente, é um crime de omissão de socorro. No entanto, investigações posteriores apuraram as circunstâncias aludidas no exemplo, diante das quais o fato passa a assumir as características de um crime de homicídio, pois a omissão de socorro funcionou como verdadeira concausa do evento letal. Face ao nosso Código que consagra a teoria da eqüivalência dos antecedentes causais, o procedimento do médico se constituíra como causa dolosa da morte, concorrendo, junto ao autor do ferimento, para êsse resultado.

\section{MAUS TRATOS}

Um tutor castiga com violência o seu tutelado, por falta cometida. O castigo, pela própria natureza e pelos meios empregados, ocasiona a morte do castigado.

Dir-se-á que o dolo sòmente poderá ser reconhecido quanto aos maus tratos inflingidos, funcionando o evento - morte - como simples condição objetiva de maior punibilidade do fato delituoso.

A solução do problema penal que se apresenta no exemplo depende intimamente de várias circunstâncias, preponderando o aspecto subjetivo: o meio utilizado para o castigo, as condições físicas da vítima, o modo de execução, o motivo, o temperamento do agente, etc.

Se a morte da pessoa decorre como uma conseqüência ordinária do próprio castigo, nas condições em que foi inflingido, e se o motivo autoriza a suspeita do "animus necandi", ao invés do aparente delito de maus tratos, poderemos ter um legítimo delito de homicídio.

A distinção entre as duas formas delituosas reside, em última análise, no elemento subjetivo.

\section{RIXA}

Se ocorre morte, a rixa é qualificada. Os rixentos não possuíam 
- "animus necandi", nem o "animus vulnerandi", mas o simples "animus rixandi". No entanto, a morte foi causada ou pela ação exclusiva de um dos participantes, ou pelo concurso de dois ou mais, ou de todos.

Todos respondem, conseqüentemente, pela rixa qualificada, respondendo ainda, em concurso material com o crime de homicídio aquêles que diretamente o causaram, salvo se conseguirem provar que o evento - morte - não pode ser imputado ao respectivo dolo. Mas, como essa indagação é de índole subjetiva, e só poderá ser exercida e resolvida através da instrução do processo e do seu julgamento, seria arbitrário. subtrair o crime à competência do júri De resto, a rixa poderá constituir simples ocasião, intencionalmente procurada, para a prática do crime de homicídio.

\section{ROUBO E EXTORSÃO}

No roubo e na extorsão, o meio executivo é a violência contra a pessoa. Como conseqüência do roubo ou da extorsão, pode resultar a morte da vítima. $\mathrm{O}$ dolo do agente que, especificamente, se dirigia à subtração da cousa, no roubo, ou à obtenção da vantagem, como condição ou preço do resgate, na extorsão, pode estender-se às 'conseqüências possíveis da violência, desde que a morte resultante se representara no espírito do agente e sua ocorrência se contivesse ordinàriamente na causalidade do fato, ligada a êste, não por um vínculo de acidentalidade, mas pela íntima relação de efeito inerente e adequado à sua causa.

Não se esqueça que ao crime de extorsão, mediante seqüestro em resultando a morte do seqüestrado, é cominada a mais rigorosa sanção penal do Código: reclusão por 20 a 30 anos e multa de 20 a 50 mil cruzeiros. Esta excepcional severidade da pena - salienta a Exposição de Motivos - é justificada pelo caráter brutal e alarmante dessa forma de criminalidade, nos tempos atuais.

Certo que o legislador pressupõe o dolo do agente, quanto ao evento "morte", pois, caso contrário, a pena não alcançaria àqueles limites extremos. E, sendo dolosa a morte, a competência para o julgamento é, obrigatòriamente, do júri. Nem se compreende que a aplicação de tal pena fôsse conferida ao juiz singular, quando delitos, como o de abôrto, se provocado pela própria gestante, punido com a pena de detenção de um a três anos, é da competência do júri

\section{CRIMES CONTRA OS COSTUMES}

No setor dos crimes contra os costumes, também surge o fator violência - como elemento integrativo do estupro, do atentado violento ao pudor, do rapto. Dêle, do fator violência, poderão derivar efeitos diversos daqueles que constituem o evento típico dêsses delitos.

Figuremos a hipótese de uma criança estuprada por um sátiro, resultando da violência a sua morte.

Outro exemplo: durante um rapto, o agente, para evitar a fuga da raptada, usa de meios compressivos e intimidantes de que resulta a sua morte.

$\mathrm{O}$ dolo do estuprador e do autor do rapto compreenderá o evento morte?

Sempre surge a mesma inquietante interrogação e a resposta não há-de variar.

Se, apuradas as circunstâncias do crime, o resultado morte fôr havido como consequiência ordinária da violência, previsto pelo agente, que dêle teve a representação, êsse resultado foi inequìvocamente abrangido pelo respectivo dolo.

\section{OUTROS CRIMES}

Resta ainda examinar os crimes previstos no Código "contra a segurança dos meios de comunicação e transporte" e "contra a saúde pública".

Aí também o evento - morte - surge, em relação a várias entidades delituosas, como condição qualificativa.

Cumpre indagar se nesse setor também se pode falar em delito doloso contra a vida

Pensamos que sim. Exemplifiquemos com duas modalidades delituosas contempladas nesses dois setores mencionados: arremêsso de projetil contra veículo em movimento e o envenenamento de fonte de água potável ou de substância alimentícia ou medicamentosa.

Quem arremessa um engenho explosivo contra um veículo em movimento, vendo-o cheio de passageiros e conhecendo a potência destruidora do projetil, não pode excluir do dolo'tôdas as conseqüências que dessa ação sobrevierem, como seja a morte de todos ou de alguns dos passageiros.

Quem envenena uma fonte de que se abastece a população de uma cidade, colocando certa quantidade de veneno capaz de matar quantos se sirvam da água, ou envenena um alimento, destinado ao consumo público, deve responder a título de dolo pela morte ou mortes que daí derivem, pois se nos afigura mais intenso o dolo, nessa hipótese, do que naquele caso em que o indivíduo mata uma pessoa determinada, porque, de algum modo, lhe dera um motivo que suscitara a sua reação homicida. Ao passo que, enevenenando uma fonte ou um medicamento, o agente vai causar a morte de pessoas que, arbsolutamente, não lhe haviam dado qualquer motivo, por mais leve que fôsse. Denota, pois, o agente profunda e fria perversidade $(8)$

(8) Telegrama de Quebec, publicado pelo "Diário de Notícias" desta capital, ediçáo
29-9-49, Informa sôbre um crime ocorrido, no Canadá "Quebec, 23 (United) foi prêsa sob a suspeita de ser antora da morte da espôsa do seu amante o de outras 
O fato da lei penal situar num ou noutro setor os diversos crimes, segundo o fim específico visado pelo agente, de que resulta a objetividade jurídica do próprio crime, consulta à necessidade de erigir um critério de classificação, mas não significa a impossibilidade do mesmo crime ser perpetrado, simultâneamente, contra diverso bem jurídico, atingido, ainda que de modo eventual, pela ação primária, cuja fôrça causal, conhecida do agente, compreendia o resultado plurilesivo.

O preceito constitucional quis dar ao júri o julgamento de todos os crimes em que a vida constitui, isoladamente ou em concurso com outro bem jurídico, a "ratio" incriminadora, desde que a lesão à vida esteja na esfera do dolo propulsor do delito.

A Constituição se apegou a um critério subjetivo para fixar a competência do júri.

A existência dêsse elemento subjetivo do crime depende sempre de ampla investigação, através das circunstâncias e dos fatôres, os mais diversos.

Só, no julgamento da causa, depois de reunidos todos os elementos elucidativos da dinâmica íntima do delito, muitas vêzes equívoca na sua morfologia, será possível apurar devidamente qual o verdadeiro elemento subjetivo: se o dolo ou a culpa "strictu sensu", fôrças morais propulsoras do crime.

Logo, a competência do júri deverá orientar-se, principalmente, pelo aspecto exterior do delito, desde que dêle se possa inferir razoàvelmente a existência do dolo contra a vida.

No caso de dúvida, o processo deve sempre ser atribuído ao júri, o que não impede que êste se declare incompetente, se dos debates resultar a prova de que, na espécie em julgamento, não se configurara, na realidade, um delito doloso contra a vida.

O júri é uma das garantias que protegem os direitos de liberdade da pessoa, declarados pela Constituição.

A lei modera - escreve Carlos Maximiliano - mas também tutela prerrogativa suprema do homem: se a limitação não é certa, se oferece margem a dúvidas por falta de clareza ou por impropriedade da linguagem, interpreta-se contra a restrição, a favor da liberdade.

\section{DOIS PROBLEMAS CONSTITUCIONAIS}

\author{
Ruy Cirne Lima
}

A elaboração da Constituição do Rio Grande do Sul propôs aos estudiosos o problema da constitucionalidade, face à Carta $\mid F$ ederal, do parlamentarismo nos Estados; e, do mesmo passo, a questão da competência para o desatamento do conflito que assim se vinha a criar entre o texto constitucional do Estado e o da União, nesse particular.

Consabida é a solução dada às duas controvérsias pelo Supremo Tribunal Federal que, reconhecendo-se competente e, pois, conhe cendo da tese "in abstracto", pronunciou a inconstitucionalidade das disposições da Constituição Estadual, de enderêço parlamentarista.

Diante dêsse aresto, e de outros, quanto à questão da competência, fiéis à mesma orientação, poderiam, talvez, considerar-se encerradas as duas questões. Pensamos, não obstante, nos possa ser perdoada a audácia de volvermos sôbre elas. Quanto ao mérito, entendemos que, de alguma forma, nos excusa a circunstância de que os argumentos, dos quais nos servimos, não entraram diretamente em discussão, ao menos em quanto se conhece, publicado, acêrca da controvérsia. Quanto à questão da competência para a solução do conflito, atemua-nos a ousadia o fato de que, depois de ter recusado a Washington, um pronunciamento "in abstracto", a Suprema Côrte dos Estados Unidos consentiu em dá-lo mais tarde, ainda que extraoficialmente, por solicitação de Monroe, para, sòmente depois, fixar-se definitivamente na posição negativa, hoje característica fundamental do sistema judiciário norte-americano. (Charles Evans Hughes, La Suprema Corte de los Estados Unidos, trad. de R. M. Pasqual e V. Herrero, México, s. d., pág. 47).

Esta, a explicação indispensável como proêmio aos dois estudos que seguem, ambos de elaboração anterior ao aresto do Supremo Tribunal Federal e o primeiro dos quais, de resto, já publicado. 